\title{
Response of the sugar maple borer to ice-damaged sugar maple in three northern hardwood stands
}

\author{
by Douglas C. Allen ${ }^{1 *}$, Jeremy Dalton ${ }^{2}$, Ralph D. Nyland ${ }^{2}$ and Eddie Bevilacqua ${ }^{2}$
}

\begin{abstract}
The purpose of this study was to investigate the response of sugar maple borer, Glycobius speciosus (Say) (Coleoptera: Cerambycidae), to crown-damaged sugar maple in three northern hardwood stands following a major icing event. The objective was to determine whether incidence of borer damage in the ten-year period following this major abiotic stress was greater than incidence during the ten-year period prior to the storm, and to evaluate whether silvicultural re-habilitation of these stands following the storm affected incidence of damage. In neither re-habilitated nor untreated plots was incidence greater post-storm.
\end{abstract}

Key words: ice storm damage, northern hardwoods, rehabilitation treatment

\begin{abstract}
RÉSUMÉ
Cette étude avait pour objectif d’analyser l'activité du perceur de lérable, Glycobius speciosus (Say) (Coléoptères : Cerambycidae), dans trois peuplements de feuillus nordiques dominés par lérables à sucre dont la cime avait été endommagée lors d’une importante tempête de verglas. Leétude visait à établir si les dégâts occasionnés par le perceur de lérable au cours des dix années qui ont suivi cet important stress abiotique étaient plus importants que ceux encourus durant les dix années précédant la tempête ainsi quà évaluer si la réhabilitation sylvicole de ces peuplements après le verglas a eu un effet sur l'incidence des dégâts. Il sest avéré qu’après la tempête, l'incidence des dégâts, n’a pas été plus importante dans les parcelles réhabilitées que dans les parcelles témoins.
\end{abstract}

Mots clés : dégât par le verglas, feuillus nordiques, traitement de réhabilitation

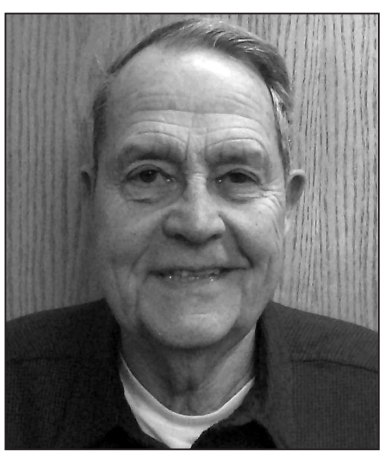

Douglas C. Allen

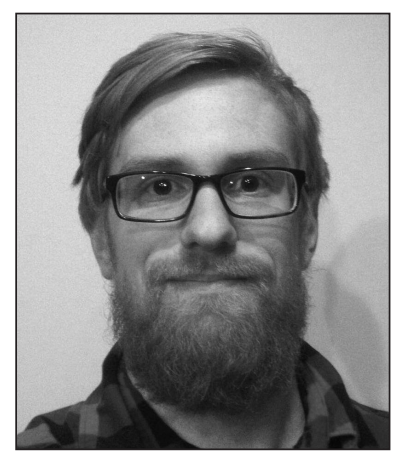

Jeremy Dalton

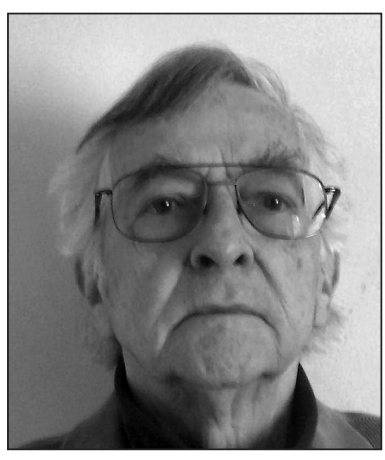

Ralph D. Nyland

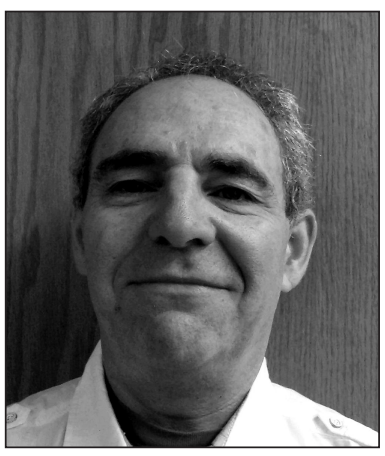

Eddie Bevilacqua

\section{Introduction}

Throughout their development, forests in North America have been vulnerable to a variety of biotic and abiotic events that can influence tree survival, tree growth and species composition. For the most part these events, either singly or in combination, are a natural part of stand development (Oliver and Larson 1990). Also, they are often important agents of natural disturbance (Lorimer 2001). Such events usually are of little economic import unless they detract from a forest owner's objective(s). For example, when the desired outcome is to produce forest products in

a northern hardwood stand, incidents that diminish wood quality, change the direction of stand development, or reduce stand density are undesirable. Crown loss and susceptibility to damage by wood boring insects and wood decay or stain that are favored by weakened or damaged sugar maples were a concern in sugarbushes affected by the 1998 ice storm in the northeastern United States (Koegl and Staats 1999) and provinces in southeastern Canada (Lautenschlager and Nielsen 1999). Organisms like these are more likely to establish in trees debilitated by crown loss (e.g., Smith et al. 2001)

\footnotetext{
${ }^{1}$ Department of Environmental and Forest Biology, State University College of Environmental Science and Forestry, Syracuse, NY 13210; * correspondence: e-mail: dcallen@esf.edu

${ }^{2}$ Department of Forest and Resources Management, State University College of Environmental Science and Forestry, Syracuse, NY 13210
} 
This major ice storm developed over extensive areas of northern New England, northern New York State (MillerWeeks and Eager 1999) and adjacent parts of Ontario, Quebec and the Maritimes (Lautenschlager and Nielsen 1999) on 5 January 1998. The storm continued at varying intensities through 11 January, and beginning on 12 January periodic high winds and varying types of precipitation and cold temperatures occurred for another ten days. Many sugarbush operations were affected for several years after this storm due to immediate and chronic tree mortality and trees with crown damage $>50 \%$ (Noland 2003). The latter was critical because crown volume of sugar maple is a major determinant of sugar production (Blum 1971) and sap quantity (Morrow 1955, Houston et al. 1990). Long-term effects on tree survival and condition have remained uncertain, both for the maple syrup producers and for landowners concerned with long-term timber production.

Perhaps anticipating important losses of these kinds, many landowners responded with intensive salvage cuttings primarily to recover the value in damaged trees. Long-term benefits from these harvests compared to alternative strategies of letting stands recover without intervention or after a rehabilitation treatment remained unclear. The latter might serve to recover the volume in badly-damaged trees and also reduce stocking around selected upper-canopy positions that showed signs of post-storm crown rebuilding. That might improve the vigor of those trees, and increase their diameter growth.

\section{Objectives}

This study was part of a broader effort to assess growth, crown condition, stand development, and other post-storm responses in three northern hardwood stands in northern New York State. It addressed two hypotheses: 1) sugar maples in the rehabilitated part of each stand were less susceptible to attack by sugar maple borer during ten years following the storm, compared to maples in a section of each stand allowed to recover without rehabilitation; and, 2) the incidence and severity of maple borer in ice-damaged stands was higher during the ten-year period following the storm then during ten years pre-storm.

Sugar maple borer (SMB), Glycobius speciosus (Say) (Order Coleoptera, Family Cerambycidae) is host-specific to sugar maple, Acer saccharum Marsh. Members of this family are commonly referred to as long-horned beetles because of the unusually long antennae characteristic of many adults. The first winter of this insect's two-year life cycle is spent as a partially grown larva in a more or less horizontal gallery it engraves at the junction of sapwood and inner bark (phloem). During year two the larva continues to feed in this region, but the gallery takes on a more vertical orientation. Beginning as early as mid-summer and into early fall of the second year, the fully grown larva leaves the feeding gallery and enters the sapwood to a depth of several centimeters where it excavates an up-ward projecting tunnel. This is where it spends the second winter.

A majority of the galleries occur on the basal $5 \mathrm{~m}$ of the tree bole (Talerico 1962, Shigo et al. 1973, Newton and Allen 1982) and when completed range from $0.8-0.9 \mathrm{~m}$ long. By the end of the second summer, gallery width can be $15 \mathrm{~mm}$ or more wide and 3-5 mm deep. The gallery is associated with dead inner bark, reddish brown stain, and a large (approxi- mately 9-11 mm) emergence hole in the outer bark. Staining is especially extensive in the bole area where the gallery is extended more or less horizontally for a short distance before the larva moves in a more vertical orientation. This can affect tree quality, because for lumber produced from most northern hardwoods, clear white wood is desired and discoloration can be as degrading as decay (Shigo 1966). Injuries of the kind caused by SMB can trigger that discoloration. This discoloration may be the host's response to physical damage. Manville and Levitin (1974) identified anti-fungal coumarins (fraxetin) associated with discoloration in maple. The outer bark covering the injury eventually dries, cracks, and is sloughed. How long the bark remains in place and whether or how soon the wound is overgrown by callus and incorporated into new growth is determined by tree vigor. Damage usually is readily identified by an open-faced scar with a more or less horizontal gallery visible on the exposed surface of the sapwood. Concealed damage may be partially covered by an area of dried, spongy bark or if the wound is old it may be partially covered by callus (Adams et al. 1995). When successfully overgrown by callus, the only external evidence of attack is a deformation in the bole and/or bark, such as a bump or ridge, or an area of sunken and slightly twisted zone of bark covering solid wood. The end result may be significant damage (defect) on the face of a butt log (Hesterberg et al. 1976), as well as lumber defects associated with discoloration, bark pockets, and seams (Lowell et al. 2013). Frequently a branch or two in the lower crown immediately above the scar will lose most of its foliage and eventually die.

\section{Methods \\ Study Sites}

The second summer following the ice storm permanent sites were located in three moderately (received $40-60 \mathrm{~mm}$ of ice) to heavily $(>60 \mathrm{~mm})$ damaged areas in north-central New York State (Risk Management Solutions, Inc. 2008). These evenaged northern hardwood stands are located at Taylor Creek State Forest in St. Lawrence County $\left(44^{\circ} 49^{\prime} \mathrm{N}, 75^{\circ} 06^{\prime} \mathrm{W}\right)$, the John MacArthur Estate in Franklin County $\left(44^{\circ} 72^{\prime} \mathrm{N}\right.$, $74^{\circ} 55^{\prime} \mathrm{W}$ ) and land owned by Boeselager Forest Enterprises in Clinton County $\left(44^{\circ} 72^{\prime} \mathrm{N}, 73^{\circ} 71^{\prime} \mathrm{W}\right.$ ) (Kraemer 2003, Nyland et al. 2016; Fig. 1).

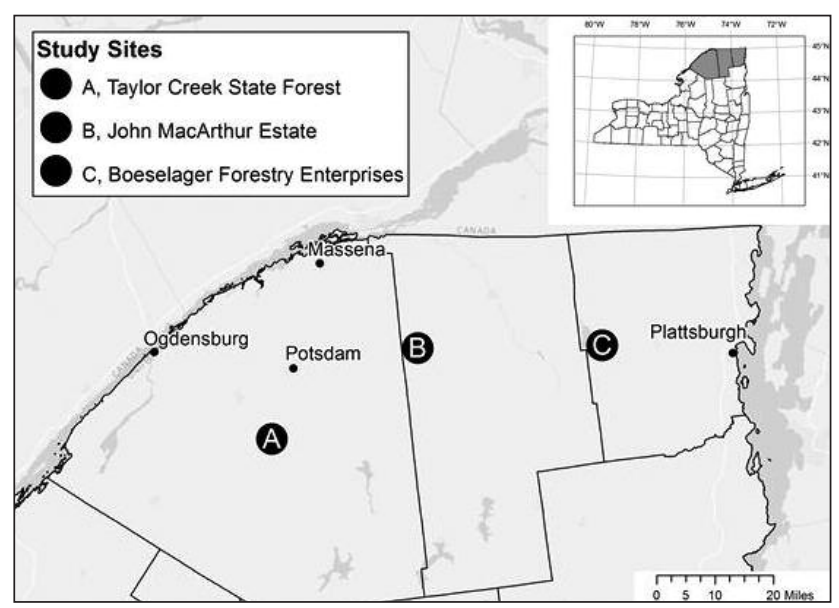

Fig. 1. Location of three study sites used to evaluate effects of the 1998 ice storm in northern New York State. 


\section{Study Design}

At each location a 12-ha section was delineated as the study site. One randomly selected half received a rehabilitation treatment and the other half was left untreated. At Taylor Creek rehabilitation was implemented in mid-October 1999, but frequent heavy rains in 2000 delayed treatment at the MacArthur Estate until summer 2001 and at the Boeselager property until fall 2001. Rehabilitation consisted of removing all main canopy trees except for selected dominant and codominants of long-lived species that exhibited signs of crown rebuilding or had some unbroken residual branches, no major structural damage to the bole, no important lean (10\%), and no evidence of cavities or fungal fruiting bodies on the bole. At Boeselager and MacArthur, previous management had triggered development of abundant advance regeneration, including trees of small sapling size. We left that cohort intact. The Taylor Creek site had a dense understory of beech (Fagus grandifolia Ehrh.) root suckers. We removed them, as well as larger beech trees, from the rehabilitated site. Rehabilitation left candidate trees with a spacing of 8-11 m $(25-35 \mathrm{ft})$ and reduced relative density to between $40 \%$ and $45 \%$. A $61 \times 61 \mathrm{~m}$ grid of $0.08 \mathrm{ha}(0.20 \mathrm{ac})$ plots was established in the middle of each 6-ha parcel (12 plots at Boeselager, 11 plots at MacArthur, 13 plots at Taylor Creek) in each of two parcels, treatment and control, in three stands (72 sample plots total). Plot centers were permanently marked in 2000 and all trees $\geq 14 \mathrm{~cm}$ diameter at breast height $(1.4 \mathrm{~m})$ within each plot received a metal tag and number to facilitate relocation and identification at a later date (Nyland et al. 2016). Crown damage (\% of crown missing following the storm) was estimated to the nearest ten percent using the method described by Woods (2002). In order to reduce variation in these estimates, tree crowns were placed in broader damage categories established by the North American Maple Project (Cooke et al. 1998): 0, 1-10\%, 11-25\%, 26-50\%, $51-76 \%, \geq 76 \%$. Lower values indicate less crown damage.

In 2010, sugar maple diameters were re-measured and crown condition (crown transparency or foliage density, an estimate of the percentage of light penetrating the foliated portion of a crown) was used as a measure of crown vigor. The lower the rating the higher the density; i.e., relatively little light penetrated through the crown. This measure of crown density was made following guidelines recommended by the USDA Forest Inventory Analysis (FIA) program (USDA Forest Service. 2007). Prior to evaluating crowns in 2010, the field crew participated in an FIA training session. For analytical purposes, each tree was assigned the upper value of its rating class for both crown damage (2000) and crown condition (2010).

Because of the nature of the rehabilitation treatment, residual trees in treated sections at each site consisted mainly of selected upper-canopy trees, and a high proportion of codominant and dominant ones, compared to a more diverse range of diameters and crown positions in untreated areas. We assumed that trees of different diameters and crown positions grow at different rates; therefore, a modified stratified sample was developed to insure a more equitable comparison of treatment effects, as well as to remove the likelihood of an unbalanced sample size between rehabilitated and untreated sections. At each untreated site, trees in the 0.08 -ha plots were sorted by diameter and species and stratified by size. From these groups, trees were selected at random from those having a range of sizes comparable to residual trees in the rehabilitated plots, i.e., dbh 14 to $85 \mathrm{~cm}$ (5.6 to 33.6 inches). Incidence of SMB and its relation to various tree and stand characteristics was evaluated using data from the stratified sample. For some of these assessments we assigned trees to broad diameter classes as follows: pole size class (14.2-29.2 $\mathrm{cm} \mathrm{dbh}$ ), small sawtimber (29.3-44.5 cm dbh), and large sawtimber $(\geq 44.6 \mathrm{~cm})$.

\section{Incidence of SMB}

During summer 2010, sugar maple trees of the stratified sample were inspected for the presence of borer damage on the basal $5.2 \mathrm{~m}$ of the bole. To age damage, a section of callus surrounding the cat-faced scar was cut from the tree. Later each sample was air-dried, stored in a small Ziplock ${ }^{\mathrm{mw}}$ bag and labeled with stand, plot and tree number. Eventually both faces of each sample were smoothed with increasingly fine sand paper (120, 150, 200 grit) and/or shaved with a sharp chisel. Growth rings were counted using a stereo-dissecting scope. Scar age was determined by the number of growth rings from immediately beneath the callus bark to the inner most ring of callus growth where the tree initiated compartmentalization of borer damage. Distorted bark or suspect bole sections with no obvious indication of borer damage were partially dissected for evidence of overgrown larval galleries. When evidence of SMB was confirmed, the tree was included when determining incidence, but damage could not be aged.

\section{Analyses}

Comparing the percent of sugar maples with evidence of borer damage occurring ten years prior to the ice storm and ten years following the storm, as well as comparing incidence within each ten-year period between treated and untreated areas at each site separately and for combined sites, were tested using a Chi-sq test and the Multiple Comparison Test of Proportions (Griffith and Santiago 2008). Similarly, this approach was used to test differences between number of scars formed in the two, ten-year intervals using incidence/year as the response variable with location, treatment and 10-year groupings. Incidence of SMB on trees with different levels of crown damage (\% broken crown) in 2000-2001 and crown condition (density) in 2010 were analyzed using a General Linear Mixed Model. When testing two or more means, the Tukey-Kramer method was used to adjust $P$ values.

\section{Results}

Sugar maple was the most abundant northern hardwood at Boeselager (50\% of the stand), and it was significantly $(P=$ 0.004) more abundant there than at the Taylor Creek (29\%). Similarly, at the MacArthur Estate sugar maple comprised a significantly $(\mathrm{P}=0.025)$ higher portion of the stand $(44 \%)$ compared to Taylor Creek. The three most abundant species ( $\%$ of all trees in plots within the untreated areas combined) were sugar maple (64\%), white ash, Fraxinus Americana L. (9\%) and red maple, Acer rubrum L. (9\%). Tree size classes were dominated by poles (54\%) and small sawtimber (39\%). The remaining $7 \%$ were large sawtimber. Mean annual diameter growth of sugar maple during the ten-year period post- 
storm was significantly higher in rehabilitated plots $(0.35 \pm$ $0.02 \mathrm{~cm} \pm \mathrm{SE})$ compared to untreated plots $(0.18 \pm 0.01)$ for all three sites combined. Within treatments, growth was similar at the three rehabilitated and the three untreated locations (Nyland et al. 2016).

Residual basal area following rehabilitation was similar for all three sites: Boeselager $\left(16.2 \mathrm{~m}^{2} / \mathrm{ha}\right)$, MacArthur (14.2 $\left.\mathrm{m}^{2} / \mathrm{ha}\right)$, Taylor Creek $\left(14.7 \mathrm{~m}^{2} / \mathrm{ha}\right)$. Stand densities in 2010 were $22.0 \mathrm{~m}^{2} / \mathrm{ha}, 11.5 \mathrm{~m}^{2} / \mathrm{ha}$, and $14.9 \mathrm{~m}^{2} /$ ha for these three sites, respectively (Nyland et al. 2016).

Average post-storm (2000) crown damage to all living trees $\geq 14.2 \mathrm{~cm}$ dbh in rehabilitated and untreated plots averaged $35 \% \pm 2 \%$ and $33 \% \pm 2 \%$, respectively. Differences between rehabilitated and untreated varied among sites. Untreated portions of the stand was significantly higher $(P=0.000)$ at Taylor Creek $(45 \% \pm 3 \%)$ compared to the other two sites; Boeselager $(32 \% \pm 3 \%)$, MacArthur $(29 \% \pm 3 \%)$. Similarly, in rehabilitated areas the average crown damage at Taylor Creek $(43 \% \pm 3 \%)$ was significantly higher $(P=0.003)$ compared to both Boeselager $(35 \% \pm 4 \%)$ and MacArthur $(21 \% \pm 3 \%)$. Average crown condition in 2010 was $34 \% \pm 2 \%$ in untreated plots and $41 \% \pm 2 \%$ in plots that received treatment (Nyland et al. 2016). Differences in crown condition in 2010 between rehabilitated and untreated were similar among the three sites $(P=0.695)$.

Table 1. Incidence [\%] of maple borer damage in the stratified sample for rehabilitated and untreated plots at each of three sites in northern New York State

\begin{tabular}{lcccc}
\hline & \multicolumn{2}{c}{$\begin{array}{l}\text { Percent of sugar maple with evidence } \\
\text { of post-stormsugar maple borer scars }\end{array}$} \\
\cline { 2 - 5 } & \multicolumn{2}{c}{ Rehabilitated } & \multicolumn{2}{c}{ Untreated } \\
\cline { 2 - 5 } Location & $\mathrm{N}$ & $(\%)$ & $\mathrm{N}$ & $(\%)$ \\
\hline Boeselager & 107 & 29.9 & 108 & 28.7 \\
Taylor State Forest & 61 & 16.4 & 57 & 21.1 \\
MacArthur Estate & 27 & 25.9 & 32 & 31.3 \\
\hline All sites & 195 & 25.1 & 197 & 26.9 \\
\hline
\end{tabular}

${ }^{1}$ Includes pre- and post-storm scars as observed 10 years after the 1998 ice storm. Tests revealed no significant differences.

Table 2. The number and incidence (\%) of maple borer scars in untreated plots ten years prior to and ten years following the 1998 ice storm in northern New York State

\begin{tabular}{lccc}
\hline Location & $\begin{array}{c}\text { Total number of scars } \\
\text { 1988-1998/1999-2001 }\end{array}$ & $\begin{array}{c}\text { Incidence of scars } \\
1988-1998 / 1999-2001\end{array}$ & $P^{1}$ \\
\hline Boeselager & $43 / 59$ & $42.2 / 57.8$ & 0.11 \\
Taylor State Forest & $12 / 15$ & $44.4 / 55.6$ & 0.56 \\
MacArthur Estate & $12 / 14$ & $46.2 / 53.9$ & 0.69 \\
\hline All trees & $67 / 88$ & $43.2 / 56.8$ & 0.09 \\
\hline
\end{tabular}

${ }^{1} P$-value for testing difference in incidence of scars between 10 -year periods prior to and following the 1998 ice storm
Table 3. Incidence [\%] of maple borer damage by crown position at three sites in northern New York State

Percent of sugar maple with evidence of sugar maple borer scars ${ }^{1}$

\begin{tabular}{lccccc}
\hline & \multicolumn{2}{c}{ Rehabilitated } & \multicolumn{4}{l}{ Untreated } \\
\hline Crown Position & $\mathrm{N}$ & $(\%)$ & $\mathrm{N}$ & $(\%)$ & $P^{2}$ \\
\hline Overtopped & - & - & - & - & - \\
Intermediate & 12 & 25.0 & 13 & 30.8 & 0.84 \\
Codominant & 40 & 22.5 & 42 & 31.0 & 0.83 \\
Dominant & 143 & 25.9 & 142 & 25.4 & 0.95 \\
\hline All trees & 185 & 25.1 & 197 & 26.9 & 0.92 \\
\hline
\end{tabular}

${ }^{1}$ Includes pre- and post-storm scars as observed 10 years after the 1998 ice storm.

Tests revealed no significant differences

${ }^{2} \mathrm{P}$-value for difference in incidence of scars on trees between rehabilitated and untreated areas

In the stratified sample, $43 \%$ of the sugar maples in all plots combined were damaged by SMB, both during the tenyear period prior to the storm (1988-1998) and ten years following the storm (1999-2009). The Multiple Comparisons Tests on Proportions indicated incidence at Boeselager (43\%) and at MacArthur (36\%) in 2010 was significantly higher compared to incidence at Taylor Creek $(17 \%)(P=0.001)$. In the untreated sample between 1988 and 1998, the incidence of damage by SMB in all of these plots (50\%) was similar to the incidence that occurred during the ten-year period poststorm (56\%). Incidence was not significantly different between treatments at any of the three sites ten years poststorm. Incidence of SMB damage was not significantly different in untreated stands in 2010 (Table 1) at Taylor Creek (21\%) compared to the untreated sample at both Boeselager (29\%) and MacArthur (31\%).

In neither the untreated nor the rehabilitated sample was incidence of SMB scars greater ten years post-storm compared to ten years prior to $1998(P=0.09$; Table 2$)$. In untreated plots, percentage of trees having at least one SMB scar did not differ significantly across locations (Table 1). Further, the percentage of trees having at least one scar by the beetle in rehabilitated plots combined across all locations during the period prior to the storm (25\%) did not differ significantly from that for the ten years following the storm $(27 \%$; Table 1). This lack of response by SMB to a silvicultural intervention is similar to that reported by Shigo et al. (1973) who were unable to show differences of damage intensity between previously cut and uncut northern hardwood stands.

In rehabilitated plots, the Multiple Comparisons Test indicated sugar maple in dominant and co-dominant crown positions grouped together did not have a significantly higher incidence of SMB damage than trees in lower canopy levels $(P=0.99)$. Incidence was similar for host trees within all crown levels of both rehabilitated and untreated samples (Table 3).

When data from the three sites were combined, the number of sugar maples damaged by maple 
borer during the post-storm period was similar even though crown condition (transparency or density) in 2010 in the rehabilitated plots $(28 \% \pm 6 \%)$ was significantly better compared to foliage in untreated plots $(59 \% \pm 4 \%)(P=0.001)$.

\section{Discussion}

Circumstances making a host suitable for wood boring cerambycids, though presumably consistent for a given species, vary from an ostensibly vigorous host condition to moribund (Hanks 1999). For many species, especially those with twoyear life cycles such as SMB, it is difficult to determine host condition at the time of attack. Maple borer rarely kills its host, though once decay occurs at the point of attack a tree may be more susceptible to breaking at that point in high winds (Baldwin 1936), an event often referred to as windsnap. Wink and Allen (2003) provided circumstantial evidence suggesting infestations of SMB increased 3-4 years following two episodes of heavy insect defoliation. Examination of nine recently dead and dying sugar maples in 1985 associated with a maple decline at the Dubuar Forest near Wanakena, New York (southern St. Lawrence County) revealed an average density of $16 \mathrm{SMB}$ galleries/tree (range 932) on the lower bole (Allen unpublished). A larger sample of these declining maples $(n=56)$ indicated average density of attack was $>5$ galleries/tree (Bauce and Allen 1992). These figures are substantially higher than average attack density of 1.4 and 2.3/tree in non-declining stands reported by Newton and Allen (1982) and Shigo et al. (1973), respectively. This evidence of an association with a stress or suite of stresses to render sugar maple susceptible to SMB, suggested excessive ice damage to maple crowns may have made trees more vulnerable to attack.

As expected, based on thinning studies (Nyland 2002, Robertson et al. 1991), average diameter growth of all sugar maples in the stratified sample increased significantly in rehabilitated plots during the ten-year period following the ice storm and growth changed little in untreated plots. Stand basal area increased significantly only in untreated plots at the MacArthur Estate. Post-storm crown damage to all trees at Taylor Creek was significantly higher compared to the other two sites in both rehabilitated (47\%) and untreated (49\%) sections of each stand, yet incidence of SMB was significantly lower at the Taylor Creek compared to the other two locations. At no location did pre- and post-storm incidence differ significantly even though growth and presumably vigor were significantly higher in rehabilitated sections of each stand. We must, therefore, reject both of our hypotheses. Crowns damaged to the extent observed at the three locations studied following the 1998 ice storm did not affect incidence of SMB in the ten-year period post-storm.

We do not know what makes a sugar maple attractive to this insect or what factor(s) facilitate successful establishment following oviposition. Susceptibility may be related to physical conditions (e.g., tree diameter, crown position, bark texture), a response to tree chemistry as reflected by tree vigor, or a combination of variables. In a review of cerambycid reproductive behavior, Hanks (1999) pointed out how difficult it can be to determine whether a tree was healthy, weakened or severely stressed at the time of host selection and successful attack by many species of long-horned beetles. Based on our observations of sugar maples damaged by SMB, in general,

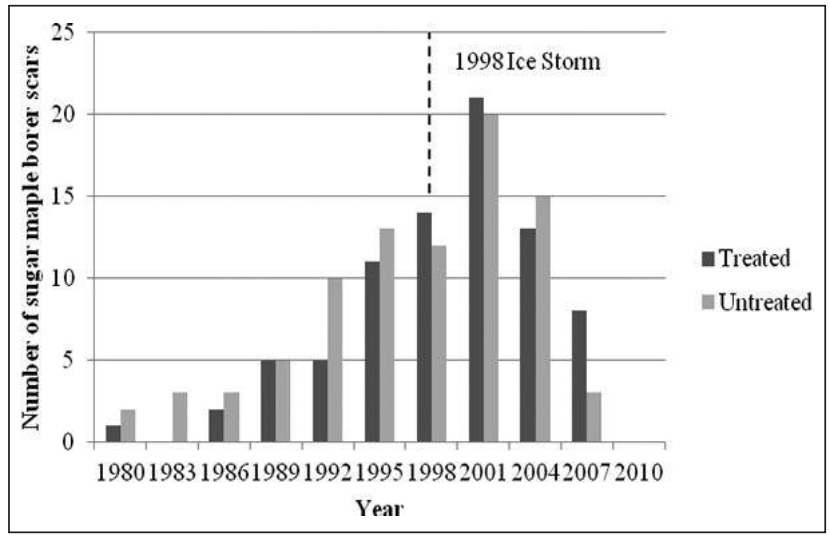

Fig. 2. Frequency distribution of sugar maple borer scars occurring from 1980 through 2001 in three stands damaged by the 1998 ice storm in northern New York State.

tree foliage on branches that survived the storm appeared healthy in terms of leaf size and color during the summers of 1998 and 1999. Limb breakage resulting from heavy ice loads reduced the crown size of most trees, but this event occurred in mid-winter after trees had stored energy in the root systems in the form of starch reserves. This apparently sustained crown rebuilding the following growing season, which may have ameliorated the impact of this physical damage on tree vigor by the time females were selecting hosts in mid-summer.

Estimates of crown damage to all trees in our ice storm plots varied from $33 \%$ to $47 \%$ (Nyland et al. 2016). This generally compares with the post-storm condition of trees reported in New England by Shortle et al. (2003). Their study examined 22000 northern hardwood trees, $79 \%$ of which had less than $50 \%$ crown loss. For this cohort there was no significant reduction in growth compared to pre-storm growth three years after the storm. A separate study by Smith (2014) at one of our sites (Taylor Creek) indicated tree growth increased the third year following the storm compared to prestorm growth.

Combined, these results suggest that branch loss during dormancy is likely to have less effect on tree vigor compared to the gradual loss of foliage during the growing season associated with stresses such as crown dieback (Renaud and Mauffette 1991) or insect defoliation (Wargo et al. 1972).

A frequency distribution of scar age for both treated and untreated areas (Fig. 2) indicates incidence of successful attacks increased from 1978 (scars counted in 1980 represent attacks occurring two years earlier) through 1999 and success decreased thereafter. We speculate it is likely the peak of successful infestation in 1999 followed by a decline in incidence may reflect the continuation of an increasing trend associated with changes in tree and stand conditions prior to the ice storm rather than a response to the impact of the storm itself.

\section{Acknowledgements}

Financial support for this study was provided by the U. S. Department of Agriculture Forest Service, Northeastern Area State and Private Forestry. The New York State Department of Environmental Conservation, Division of Lands and Forests, 
Potsdam, NY and Herbert Boyce, consulting forester, Jay, NY assisted in identifying research sites. We thank Kim Adams and Melissa Fierke, State University College of Environmental Science and Forestry for reviewing early drafts of the manuscript.

\section{References}

Adams, K.B., D.C. Allen, P.D. Manion and L.P. Abrahamson. 1995. The stewardship of northern hardwoods. St. Univ. of New York. Coll. Environ. Sci. and Forestry, Syracuse.

Baldwin, 1936. The sugar-maple borer. Mass. Forest and Park Assoc., Boston, MA. Leaflet No. 8.

Bauce, E. and D.C. Allen. 1992. Role of Armellaria calvescens and Glycobius speciosus in a sugar maple decline. Can. J. For. Res. 22(4): 549-552.

Blum, B.N. 1971. Some correlations between sugar maple tree characteristics and sap yield. U. S. Department of Agriculture, For. Serv. Res. Note NE-143, Upper Darby, PA.

Cooke, R., D. Lachance, W. Burkman and D. Allen. 1998. North American sugar maple decline project: Organization and field methods. Updated from: U. S. Department of Agriculture, For. Serv. Gen. Tech. Rep. NE-154, Radnor, PA.

Griffith, D. and E. Santiago. 2008. Multiple comparison tests on proportions code. Available on line at http://www.minitab.com/ en-TW/macros/default.aspx?action=code\&id=106; last accessed Nov. 2, 2012.

Hanks, L.M. 1999. Influence of the larval host plant on reproductive strategies of cerambycid beetles. Ann. Rev. Entomol. 44: 483-505.

Hesterberg, G.A., C.J. Wright and D.J. Frederick. 1976. Decay risk for sugar maple borer scars. J. For. 74(7): 443-445.

Houston, D.R., D.C. Allen and D. Lachance. 1990. Sugarbush management: a guide to maintaining tree health. U. S. Department of Agriculture For. Serv., Gen. Tech. Rep. NW-129.

Koegl, J. and L. Staats. 1999. Looking beyond the ice storm, studying recovery in New York sugarbushes. Farming. April 1999: 45-50. Kraemer, M.J. 2003. Hardwood crown loss and subsequent rebuilding in northern New York State following the January 1998 ice storm. M.Sc. thesis. State University College of Environmental Science and Forestry. Syracuse, NY.

Lautenschlager, R.A. and C. Nielsen. 1999. Ontario's forest science efforts following the 1998 ice storm. Forest. Chron. 75(4): 633-641. Lorimer, C.G. 2001. Historical and ecological roles of disturbance in eastern North American forests. Wildlife Soc. Bull. 29(2): 425-439. Lowell, E.C., J.K. Wiedenbeck and B.S. Porterfield. 2013. A photographic guide to Acacia koa defects. U.S. Department of Agriculture For. Serv., Pacific NW Research Station Gen. Tech. Rep. PNWGTR-871.

Manville, J.F. and N. Levitin. 1974. Anti-fungal coumarins from mineral stained maple. Can. For. Serv. Bimon. Res. Notes. 30(1): 3-4 Miller-Weeks, M. and C. Eager. 1999. The northeastern ice storm 1998: A forest damage assessment for New York, Vermont, New Hampshire, and Maine. Concord, NH: Northeast State Forester's Association, and Durham, NH: U. S. Department of Agriculture For. Serv., State and Private Forestry.
Morrow, R.E. 1955. Influence of tree crowns on maple sap production. Cornell Univ. Agr. Exp. Sta. Bull. 916.

Newton, W.G. and D.C. Allen. 1982. Characteristics of trees damaged by sugar maple borer, Glycobius speciosus (Say). Can J. For. Res. 12(4): 738-744

Noland, T.L. 2003. 1998 ice storm impact on sugarbushes of eastern Ontario. For. Chron. 79(1): 75-81.

Nyland, R.D. 2002. Silviculture: Concepts and application. Waveland Press, Long Grove, IL. $2^{\text {nd }}$ ed.

Nyland, R.D., J.L. Dalton, D.C. Allen and E. Bevilacqua. 2016. Response of ice-damaged northern hardwood stands in northern New York. Forest. Chron. 92(1): 78-90.

Oliver, C.D. and B.C. Larson. 1990. Forest Stand Dynamics. McGraw-Hill, New York.

Renaud, J.-P. and Y. Mauffette. 1991. The relationships of crown dieback with carbohydrate content and growth of sugar maple (Acer saccharum). Can J. For. Res. 21(7): 1111-1118.

Risk Management Solutions, Inc. 2008. The 1998 ice storm: 10year retrospective rms special report. Available online at http:// www.rms.com/puglications/1998_ice_storm_retrospective.pdf; last accessed Apr. 14, 2012.

Roberston, R.G., R.W. Young and J.C. Lees. 1991. Hardwood Thinning Manual. Nova Scotia Dept. Natural Resources, Extension Services Division.

Shigo, A.L. 1966. Decay and discoloration following logging wounds on northern hardwoods. U.S. Department of Agriculture. For. Serv. Res. Pap. NE-47, Upper Darby, PA.

Shigo, A.L., W.B. Leak and S.M. Filip. 1973. Sugar maple borer injury in four hardwood stands in New Hampshire. Can. J. For. Res. 3(4): 512-515

Shortle, W.C., K.T. Smith and K.R. Dudzik. 2003. Tree survival and growth following ice storm injury. Res. Pap. NE-723. Newton Square, PA. U.S.D.A. Dept. of Agriculture, For. Serv., Northeastern Research Station. 4 p.

Smith, K.T., W.C. Shortle and K.R. Dudzik. 2001. Patterns of storm injury and tree response. U. S. Department of Agriculture For. Serv., Northeastern Area State \& Private Forestry NA-TP-02-01.

Smith, T. 2014. Growth response patterns of sugar maple pre- and post-1998 ice storm disturbance in northern hardwood forest. M.Sc. thesis, State University College of Environmental Science and Forestry, Syracuse.

Talerico, R.L. 1962. A study of damage caused by the sugar maple borer. J. For. 60(3): 178-180.

U. S. Department of Agriculture Forest Service 2007. Forest inventory and analysis phase 3 field guide-crowns: measurements and sampling version 4.0 measurements and sampling, version 4 .

Wargo, P.M., J. Parker and D.R. Houston. 1972. Starch content in roots of defoliated sugar maple. For. Sci. 18(3): 203-204.

Wink, R.A. and D.C. Allen. 2003. Sugar maple borer (Coleoptera:Cerambycidae) activity associated with periods of severe defoliation. The Great Lakes Entomologist. 36(1): 11-14.

Woods, S.S. 2002. Response of ferns to overstory disturbance: effects of ice storm and timber harvest on four common fern species in hardwood forests of New York. M.Sc. thesis, St. Univ. of New York, Coll. Environ. Sci. and Forestry, Syracuse. 